\title{
Synthesis, Crystal Structures and Catalytic Property of Dioxomolybdenum(VI) and Nickel(II) Complexes Derived from bis-Schiff Bases
}

\author{
Ling-Wei Xue, ${ }^{*}$ Qin-Long Peng, Pan-Pan Wang, Hui-Jie Zhang \\ College of Chemistry and Chemical Engineering, Pingdingshan University, Pingdingshan Henan 467000, P.R. China \\ *Corresponding author: E-mail: pdsuchemistry@163.com
}

Received: 03-26-2019

\begin{abstract}
A new mononuclear dioxomolybdenum(VI) complex, $\left[\mathrm{MoO}_{2} \mathrm{~L}^{1}\right]$, and a new linear trinuclear nickel(II) complex, $\left[\mathrm{Ni}\left\{\mathrm{NiL}^{2}\left(\mu_{1}-\eta^{1}: \eta^{0}-\mathrm{OAc}\right)\left(\mu_{2}-\eta^{1}: \eta^{1}-\mathrm{OAc}\right)\right\}_{2}\right] \cdot \mathrm{H}_{2} \mathrm{O}$, where $\mathrm{L}^{1}$ is the dianionic form of $N, N^{\prime}$-bis(5-fluorosalicylidene)-1,3-propanediamine $\left(\mathrm{H}_{2} \mathrm{~L}^{1}\right), \mathrm{L}^{2}$ is the dianionic form of $N, N^{\prime}$-bis(5-fluoro-2-hydroxybenzylidene)-2-hydroxy1,3-propanediamine $\left(\mathrm{H}_{2} \mathrm{~L}^{2}\right)$, have been synthesized and characterized by elemental analysis, FT-IR spectroscopy, and single-crystal X-ray determination. The Mo atom in the molybdenum complex is coordinated by four donor atoms of the Schiff base ligand, and two oxo groups, forming an octahedral coordination. In the nickel complex, there are three bridges across the Ni-Ni atom pairs, involving two phenolate $\mathrm{O}$ atoms of a Schiff base ligand, and an $\mathrm{O}-\mathrm{C}-\mathrm{O}$ moiety of a $\mu_{2}-\eta^{1}: \eta^{1}$-OAc group. The central $\mathrm{Ni}$ atom is located on an inversion center and has octahedral coordination involving four bridging $\mathrm{O}$ atoms from two Schiff base ligands in the equatorial plane and two $\mathrm{O}$ atoms from two $\mu_{2}-\eta^{1}: \eta^{1}-\mathrm{OAc}$ ligands in the axial positions. The coordination around the terminal $\mathrm{Ni}$ atoms is also octahedral, with two imino $\mathrm{N}$ and two phenolate $\mathrm{O}$ atoms from a Schiff base ligand defining the equatorial plane, and with two $\mathrm{O}$ atoms respectively from a $\mu_{1}-\eta^{1}: \eta^{0}$-OAc and a $\mu_{2}-\eta^{1}: \eta^{1}$-OAc ligands occupying the axial positions. The molybdenum complex has excellent catalytic property for sulfoxidation reactions.
\end{abstract}

Keywords: Dioxomolybdenum complex; nickel complex; Schiff base; Crystal structure; Sulfoxidation

\section{Introduction}

Molybdenum and nickel complexes with multi-dentate ligands have received remarkable attention in recent years for their catalytic properties ${ }^{1}$ and molecular structures. ${ }^{2}$ Salicylaldehyde and its derivatives have been widely used as ligands for the preparation of metal complexes with various applications. ${ }^{3}$ A large number of molybdenum and nickel complexes with Schiff bases have been reported. ${ }^{4}$ Some of the complexes have shown oxygen atom transfer properties as they were found to oxidize thiols, hydrazine, polyketones, and tertiary phosphines. ${ }^{5}$ Recently, we have reported some molybdenum and manganese complexes derived from hydrazone type ligands, and show interesting catalytic properties. ${ }^{6}$ We report in this paper the syntheses, crystal structures and catalytic property of a<smiles>Oc1ccc(F)cc1/C=N/CCC/N=C/c1cc(F)ccc1O</smiles>

new dioxomolybdenum(VI) complex, $\left[\mathrm{MoO}_{2} \mathrm{~L}^{1}\right]$, and a new linear trinuclear nickel(II) complex, $\left[\mathrm{Ni}\left\{\mathrm{NiL}^{2}\right.\right.$ $\left.\left.\left(\mu_{1}-\eta^{1}: \eta^{0}-\mathrm{OAc}\right)\left(\mu_{2}-\eta^{1}: \eta^{1}-\mathrm{OAc}\right)\right\}_{2}\right] \cdot \mathrm{H}_{2} \mathrm{O}$, where $\mathrm{L}^{1}$ is the dianionic form of $N, N^{\prime}$-bis(5-fluorosalicylidene)-1,3-propanediamine $\left(\mathrm{H}_{2} \mathrm{~L}^{1}\right), \mathrm{L}^{2}$ is the dianionic form of $N, N^{\prime}$ bis(5-fluoro-2-hydroxybenzylidene)-2-hydroxy-1,3-propanediamine $\left(\mathrm{H}_{2} \mathrm{~L}^{2}\right.$; Scheme 1).

\section{Experimental}

\section{1. Materials and Methods}

5-Fluorosalicylaldehyde, propane-1,3-diamine and 2-hydroxyl-1,3-propanediamine were purchased from Fluka. Other reagents and solvents were analytical grade<smiles>Oc1ccc(F)cc1/C=N/CC(O)C/N=C/c1cc(F)ccc1O</smiles> 
and used without further purification. The Schiff bases $\mathrm{H}_{2} \mathrm{~L}^{1}$ was prepared according to the literature method. ${ }^{7} \mathrm{El}-$ emental $(\mathrm{C}, \mathrm{H}$, and $\mathrm{N})$ analyses were made on a Perkin-Elmer Model 240B automatic analyzer. IR spectra were recorded on an IR-408 Shimadzu 568 spectrophotometer. ${ }^{1} \mathrm{H}$ NMR spectra were recorded on a Bruker 300 $\mathrm{MHz}$ instrument.

\section{2. Synthesis of $\mathrm{H}_{2} \mathrm{~L}^{2}$}

5-Fluorosalicylaldehyde ( $2.0 \mathrm{mmol}, 0.28 \mathrm{~g}$ ) was dissolved in methanol $(20 \mathrm{~mL})$, to which was added dropwise a methanol solution $(10 \mathrm{~mL})$ of 2-hydroxy-1,3-propanediamine $(1.0 \mathrm{mmol}, 0.090 \mathrm{~g})$ with stirring at room temperature. The mixture was stirred at room temperature for 30 min, and most of the solvent was removed by distillation. The yellow crystalline product was obtained by filtration. Yield: $93 \%$. IR data $\left(\mathrm{cm}^{-1}, \mathrm{KBr}\right): 3370 \mathrm{~m}, 1638 \mathrm{~s}, 1587 \mathrm{~s}$, $1492 \mathrm{~s}, 1450 \mathrm{w}, 1387 \mathrm{w}, 1318 \mathrm{w}, 1263 \mathrm{~s}, 1216 \mathrm{~m}, 1142 \mathrm{~m}$, 1090w, 1040m, 966w, 878m, 822s, 784s, 673w, 577w, 456w. ${ }^{1} \mathrm{H}$ NMR (300 MHz, DMSO) $\delta 12.72(\mathrm{~s}, 2 \mathrm{H}, \mathrm{OH}), 8.51$ (s, $2 \mathrm{H}, \mathrm{CH}=\mathrm{N}), 7.35$ (dd, J = 8.9, 3.1 Hz, 2H, ArH), 7.19 (td, J $=8.7,3.2 \mathrm{~Hz}, 2 \mathrm{H}, \mathrm{ArH}), 6.89(\mathrm{dd}, \mathrm{J}=9.0,4.5 \mathrm{~Hz}, 2 \mathrm{H}, \mathrm{ArH})$, $4.04(\mathrm{~s}, 1 \mathrm{H}, \mathrm{OH}), 3.79\left(\mathrm{dd}, \mathrm{J}=12.1,4.0 \mathrm{~Hz}, 2 \mathrm{H}, \mathrm{CH}_{2}\right), 3.61$ $\left(\mathrm{dd}, \mathrm{J}=12.1,6.6 \mathrm{~Hz}, 2 \mathrm{H}, \mathrm{CH}_{2}\right) \cdot{ }^{13} \mathrm{C} \mathrm{NMR}(75 \mathrm{MHz}$, DMSO) $\delta 156.98,156.12,153.02,119.32,119.01,118.81$, 116.71, 69.22, 62.87. Anal. Calcd. (\%) for $\mathrm{C}_{17} \mathrm{H}_{16} \mathrm{~F}_{2} \mathrm{~N}_{2} \mathrm{O}_{3}$ : C, 61.07; H, 4.82; N, 8.38. Found (\%): C, 61.26; H, 4.73; N, 8.29 .

\section{3. Synthesis of the Molybdenum Complex}

$\mathrm{MoO}_{2}(\mathrm{acac})_{2}(0.1 \mathrm{mmol}, 33.5 \mathrm{mg})$ in methanol (10 $\mathrm{mL})$ was added with stirring to $\mathrm{H}_{2} \mathrm{~L}(0.1 \mathrm{mmol}, 31.8 \mathrm{mg})$ in methanol $(10 \mathrm{~mL})$. The mixture was stirred at refluxed for $30 \mathrm{~min}$ to give a yellow solution. The solution was left still at room temperature in air to give yellow block-shaped single crystals, which were collected by filtration and dried in vacuum containing anhydrous $\mathrm{CaCl}_{2}$. Yield: $52 \%$. IR data $\left(v, \mathrm{~cm}^{-1}\right): 1621 \mathrm{~s}, 1547 \mathrm{~m}, 1471 \mathrm{~s}, 1381 \mathrm{~m}, 1266 \mathrm{~s}, 1153$ s, $1076 \mathrm{w}, 977 \mathrm{~m}, 895 \mathrm{~m}, 820 \mathrm{~m}, 743 \mathrm{w}, 703 \mathrm{w}, 659 \mathrm{w}, 620 \mathrm{w}$, $571 \mathrm{w}, 515 \mathrm{w}, 449 \mathrm{w}, 415 \mathrm{w}$. UV-vis data in methanol [ $\lambda_{\max }$ (nm), $\left.\varepsilon\left(\mathrm{L} \mathrm{mol}^{-1} \mathrm{~cm}^{-1}\right)\right]: 270,12380 ; 325,9310 ; 420,2115$. Anal. Calcd. (\%) for $\mathrm{C}_{17} \mathrm{H}_{14} \mathrm{~F}_{2} \mathrm{MoN}_{2} \mathrm{O}_{4}$ : C, 45.96; $\mathrm{H}, 3.18$; N, 6.31. Found (\%): C, 45.75; H, 3.27; N, 6.24 .

\section{4. Synthesis of the Nickel Complex}

$\mathrm{H}_{2} \mathrm{~L}^{2}$ (0.3 mmol, $100.2 \mathrm{mg}$ ) was dissolved in methanol $(20 \mathrm{~mL})$, to which was added a methanol-water solution $(20 \mathrm{~mL}, \mathrm{~V}: \mathrm{V}=10: 1)$ of nickel acetate tetrahydrate $(0.5$ $\mathrm{mmol}, 124.5 \mathrm{mg}$ ) with stirring. The mixture was stirred at room temperature for $30 \mathrm{~min}$ to give a green solution, which was kept still to slow evaporate of the solvents. Green block-like single crystals suitable for X-ray diffraction were formed. Yield: $37 \%$. IR data $\left(v, \mathrm{~cm}^{-1}\right): 3426 \mathrm{w}$,
1634 s, 1563 s, 1472 s, 1425 m, 1398 m, 1302 m, 1252 w, $1213 \mathrm{w}, 1147 \mathrm{~m}, 1059 \mathrm{w}, 957 \mathrm{w}, 862 \mathrm{w}, 817 \mathrm{~s}, 679 \mathrm{w}, 616 \mathrm{w}$, $574 \mathrm{w}, 475 \mathrm{w}$. UV-vis data in methanol $\left[\lambda_{\max }(\mathrm{nm}), \varepsilon(\mathrm{L}\right.$ $\left.\mathrm{mol}^{-1} \mathrm{~cm}^{-1}\right)$ ]: 361, 41900; 255, 48010; 235, 49132. Anal. Calcd. (\%) for $\mathrm{C}_{42} \mathrm{H}_{42} \mathrm{~F}_{4} \mathrm{~N}_{4} \mathrm{Ni}_{3} \mathrm{O}_{15}$ : C, 46.07; H, 3.87; N, 5.12. Found (\%): C, 45.88; H, 3.97; N, 5.26.

\section{5. X-ray Diffraction}

Data were collected from selected crystals mounted on a glass fiber. The data for the complexes were processed with SAINT ${ }^{8}$ and corrected for absorption using SADABS. ${ }^{9}$ Multi-scan absorption corrections were applied with $\omega$ scans. ${ }^{10}$ The structures of the complexes were solved by direct method using SHELXS-97 program and refined by full-matrix least-squares techniques on $F^{2}$ using anisotropic displacement parameters. ${ }^{11}$ All non-hydrogen atoms were refined anisotropically. The water $\mathrm{H}$ atoms in the nickel complex were located in a difference Fourier map and refined isotropically, with $\mathrm{O}-\mathrm{H}$ and $\mathrm{H} \cdots \mathrm{H}$ distances restrained to $0.85(1)$ and $1.37(2) \AA$, respectively. The remaining hydrogen atoms were placed at the calculated positions. The C8-C9-C10-O7 moiety in the nickel complex is disordered over two sites, with occupancies of $0.532(3)$ and 0.468(3). Crystallographic data for the complex are listed in Table 1. Selected bond lengths and angles are given in Table 2.

Table 1. Crystallographic data and structure refinement for the complexes

\begin{tabular}{|c|c|c|}
\hline & $\begin{array}{l}\text { The molybdenum } \\
\text { complex }\end{array}$ & $\begin{array}{l}\text { The nickel } \\
\text { complex }\end{array}$ \\
\hline Molecular formula & \multicolumn{2}{|l|}{$\mathrm{C}_{17} \mathrm{H}_{14} \mathrm{~F}_{2} \mathrm{MoN}_{2} \mathrm{O}_{4}$} \\
\hline \multicolumn{3}{|l|}{$\mathrm{C}_{42} \mathrm{H}_{42} \mathrm{~F}_{4} \mathrm{~N}_{4} \mathrm{Ni}_{3} \mathrm{O}_{15}$} \\
\hline Formula weight & 444.24 & 1094.93 \\
\hline Crystal system & Monoclinic & Monoclinic \\
\hline Space group & $P 2_{1} / c$ & $P 2_{1} / n$ \\
\hline$a, \AA$ & $10.689(2)$ & $12.548(1)$ \\
\hline$b, \AA$ & $17.327(2)$ & $13.188(1)$ \\
\hline$c, \AA$ & $9.001(1)$ & $15.065(1)$ \\
\hline$\beta,{ }^{\circ}$ & $103.175(2)$ & $112.789(3)$ \\
\hline$V, \AA^{3}$ & $1623.2(4)$ & $2298.3(4)$ \\
\hline$Z$ & 4 & 2 \\
\hline$F(000)$ & 888 & 1124 \\
\hline$\mu(\mathrm{MoK \alpha}), \mathrm{mm}^{-1}$ & 0.857 & 1.305 \\
\hline Collected reflections & 14985 & 21744 \\
\hline Independent reflections & 2885 & 4270 \\
\hline Observed reflections $(I \geq 2 \sigma(I)$ & (I)) 2494 & 3077 \\
\hline Restraints/parameters & $0 / 235$ & $17 / 342$ \\
\hline Goodness of fit on $F^{2}$ & 1.063 & 1.056 \\
\hline$R_{\text {int }}$ & 0.0285 & 0.0439 \\
\hline$R_{1}, w R_{2}(I \geq 2 \sigma(I)]^{*}$ & $0.0248,0.0570$ & $0.0588,0.1660$ \\
\hline$R_{1}, w R_{2}$ (all data) ${ }^{*}$ & $0.0330,0.0607$ & $0.0876,0.1914$ \\
\hline$\Delta \rho_{\max }, \Delta \rho_{\min }, e \AA^{-3}$ & $0.303,-0.354$ & $1.028,-0.665$ \\
\hline
\end{tabular}


Table 2. Selected bond lengths $(\AA)$ and angles $\left(^{\circ}\right)$ for the complexes

\begin{tabular}{|c|c|c|c|}
\hline \multicolumn{4}{|c|}{ The molybdenum complex } \\
\hline $\mathrm{Mo}(1)-\mathrm{O}(1)$ & $1.9290(17)$ & $\mathrm{Mo}(1)-\mathrm{O}(2)$ & $2.0935(17)$ \\
\hline $\mathrm{Mo}(1)-\mathrm{O}(3)$ & $1.7016(17)$ & $\mathrm{Mo}(1)-\mathrm{O}(4)$ & $1.7040(18)$ \\
\hline $\operatorname{Mo}(1)-\mathrm{N}(1)$ & $2.317(2)$ & $\operatorname{Mo}(1)-\mathrm{N}(2)$ & $2.169(2)$ \\
\hline $\mathrm{O}(3)-\mathrm{Mo}(1)-\mathrm{O}(4)$ & $104.27(9)$ & $\mathrm{O}(3)-\mathrm{Mo}(1)-\mathrm{O}(1)$ & $102.08(8)$ \\
\hline $\mathrm{O}(4)-\mathrm{Mo}(1)-\mathrm{O}(1)$ & $101.45(9)$ & $\mathrm{O}(3)-\mathrm{Mo}(1)-\mathrm{O}(2)$ & $89.80(8)$ \\
\hline $\mathrm{O}(4)-\mathrm{Mo}(1)-\mathrm{O}(2)$ & $159.93(8)$ & $\mathrm{O}(1)-\mathrm{Mo}(1)-\mathrm{O}(2)$ & $89.22(7)$ \\
\hline $\mathrm{O}(3)-\mathrm{Mo}(1)-\mathrm{N}(2)$ & $93.80(8)$ & $\mathrm{O}(4)-\mathrm{Mo}(1)-\mathrm{N}(2)$ & $86.32(9)$ \\
\hline $\mathrm{O}(1)-\mathrm{Mo}(1)-\mathrm{N}(2)$ & $159.85(8)$ & $\mathrm{O}(2)-\mathrm{Mo}(1)-\mathrm{N}(2)$ & $78.42(7)$ \\
\hline $\mathrm{O}(3)-\mathrm{Mo}(1)-\mathrm{N}(1)$ & $168.13(8)$ & $\mathrm{O}(4)-\mathrm{Mo}(1)-\mathrm{N}(1)$ & $85.67(8)$ \\
\hline $\mathrm{O}(1)-\mathrm{Mo}(1)-\mathrm{N}(1)$ & $81.88(7)$ & $\mathrm{O}(2)-\mathrm{Mo}(1)-\mathrm{N}(1)$ & $79.00(7)$ \\
\hline $\mathrm{N}(2)-\mathrm{Mo}(1)-\mathrm{N}(1)$ & $80.19(8)$ & & \\
\hline \multicolumn{4}{|l|}{ The nickel complex } \\
\hline $\mathrm{Ni}(1)-\mathrm{O}(1)$ & $2.061(3)$ & $\mathrm{Ni}(1)-\mathrm{O}(2)$ & $2.053(3)$ \\
\hline $\mathrm{Ni}(1)-\mathrm{O}(6)$ & $2.044(4)$ & $\mathrm{Ni}(2)-\mathrm{O}(1)$ & $1.995(3)$ \\
\hline $\mathrm{Ni}(2)-\mathrm{O}(2)$ & $1.990(3)$ & $\mathrm{Ni}(2)-\mathrm{O}(3)$ & $2.177(5)$ \\
\hline $\mathrm{Ni}(2)-\mathrm{O}(5)$ & $2.066(5)$ & $\mathrm{Ni}(2)-\mathrm{N}(1)$ & $2.014(4)$ \\
\hline $\mathrm{Ni}(2)-\mathrm{N}(2)$ & $2.016(5)$ & & \\
\hline $\mathrm{O}(6)-\mathrm{Ni}(1)-\mathrm{O}(6 \mathrm{~A})$ & 180 & $\mathrm{O}(6)-\mathrm{Ni}(1)-\mathrm{O}(2)$ & $89.0(2)$ \\
\hline $\mathrm{O}(6)-\mathrm{Ni}(1)-\mathrm{O}(2 \mathrm{~A})$ & $91.0(2)$ & $\mathrm{O}(2)-\mathrm{Ni}(1)-\mathrm{O}(2 \mathrm{~A})$ & 180 \\
\hline $\mathrm{O}(6)-\mathrm{Ni}(1)-\mathrm{O}(1)$ & $90.1(1)$ & $\mathrm{O}(6)-\mathrm{Ni}(1)-\mathrm{O}(1 \mathrm{~A})$ & $89.9(1)$ \\
\hline $\mathrm{O}(2)-\mathrm{Ni}(1)-\mathrm{O}(1)$ & $79.4(1)$ & $\mathrm{O}(2)-\mathrm{Ni}(1)-\mathrm{O}(1 \mathrm{~A})$ & $100.6(1)$ \\
\hline $\mathrm{O}(1)-\mathrm{Ni}(1)-\mathrm{O}(1 \mathrm{~A})$ & 180 & $\mathrm{O}(2)-\mathrm{Ni}(2)-\mathrm{O}(1)$ & $82.5(1)$ \\
\hline $\mathrm{O}(2)-\mathrm{Ni}(2)-\mathrm{N}(1)$ & $172.8(2)$ & $\mathrm{O}(1)-\mathrm{Ni}(2)-\mathrm{N}(1)$ & $90.8(2)$ \\
\hline $\mathrm{O}(2)-\mathrm{Ni}(2)-\mathrm{N}(2)$ & $90.2(2)$ & $\mathrm{O}(1)-\mathrm{Ni}(2)-\mathrm{N}(2)$ & $171.5(2)$ \\
\hline $\mathrm{N}(1)-\mathrm{Ni}(2)-\mathrm{N}(2)$ & $96.2(2)$ & $\mathrm{O}(2)-\mathrm{Ni}(2)-\mathrm{O}(5)$ & $91.3(2)$ \\
\hline $\mathrm{O}(1)-\mathrm{Ni}(2)-\mathrm{O}(5)$ & $90.7(2)$ & $\mathrm{N}(1)-\mathrm{Ni}(2)-\mathrm{O}(5)$ & $91.5(2)$ \\
\hline $\mathrm{N}(2)-\mathrm{Ni}(2)-\mathrm{O}(5)$ & $93.8(2)$ & $\mathrm{O}(2)-\mathrm{Ni}(2)-\mathrm{O}(3)$ & $92.6(2)$ \\
\hline $\mathrm{O}(1)-\mathrm{Ni}(2)-\mathrm{O}(3)$ & $90.2(2)$ & $\mathrm{N}(1)-\mathrm{Ni}(2)-\mathrm{O}(3)$ & $84.7(2)$ \\
\hline $\mathrm{N}(2)-\mathrm{Ni}(2)-\mathrm{O}(3)$ & $85.8(2)$ & $\mathrm{O}(5)-\mathrm{Ni}(2)-\mathrm{O}(3)$ & $176.2(2)$ \\
\hline
\end{tabular}

\section{6. Catalytic Oxidation}

The complexes $\left(0.001 \mathrm{~mol} \mathrm{~L}^{-1}\right)$ and phenyl methyl sulfide $\left(0.100 \mathrm{~mol} \mathrm{~L}^{-1}\right)$ were dissolved at room temperature in a mixture of $\mathrm{CH}_{2} \mathrm{Cl}_{2}$ and $\mathrm{CH}_{3} \mathrm{OH}$ (6:4) together with 1,3,5-trimethoxybenzene $\left(0.100 \mathrm{~mol} \mathrm{~L}^{-1}\right)$ as internal standard. The resulting solution was cooled to $283 \mathrm{~K}$ and $\mathrm{H}_{2} \mathrm{O}_{2}(35 \% \mathrm{w} / \mathrm{w})$ added dropwise $\left(0.125 \mathrm{~mol} \mathrm{~L}^{-1}\right)$. An aliquot of the reaction solution $(2.0 \mathrm{~mL})$ was quenched with $5.0 \mathrm{~mL}$ of a stock solution of $\mathrm{Na}_{2} \mathrm{SO}_{3}\left(0.100 \mathrm{~mol} \mathrm{~L}^{-1}\right)$ and extracted with dichloromethane (three times $4 \mathrm{~mL}$ ). From the collected organic phases the solvent was removed under reduced pressure to complete dryness and the residue redissolved in deuterated chloroform $(0.60 \mathrm{~mL})$ and analyzed by ${ }^{1} \mathrm{H}$ NMR to determine the yield with reference to the internal standard 1,3,5-trimethoxybenzene.

\section{Results and Discussion}

\section{1. Chemistry}

Reaction of the Schiff base $\mathrm{H}_{2} \mathrm{~L}^{1}$ with $\mathrm{MoO}_{2}(\mathrm{acac})_{2}$, and $\mathrm{H}_{2} \mathrm{~L}^{2}$ with $\mathrm{Ni}\left(\mathrm{CH}_{3} \mathrm{COO}\right)_{2}$, respectively, afforded the molybdenum and nickel complexes. The complexes are soluble in DMF, DMSO, methanol, ethanol and acetonitrile. We have attempted to grow diffraction quality crystals from various solvents, however, well-shaped single crystals suitable for X-ray diffraction can only be obtained from methanol solution.

\section{2. Structure Description of the Molybdenum Complex}

The molecular structure of the complex is shown in Fig. 1. The coordination geometry around the Mo atom in the complex is octahedrally distorted. The Schiff base ligand coordinates to the Mo atom through two phenolate $\mathrm{O}$ and two imino $\mathrm{N}$ atoms, forming three six-membered chelate rings with the Mo atom. The other two sites are coordinated by two oxo groups. Atoms $\mathrm{O}(1), \mathrm{N}(1), \mathrm{N}(2)$ and $\mathrm{O}(3)$ located at the equatorial plane show a high degree of planarity, with mean deviation from the plane of $0.002(3) \AA$. The $\mathrm{Mo}(1)$ atom deviates from the leastsquares plane defined by the four equatorial donor atoms by $0.185(2) \AA$ in the direction of the axial atom O(4). The angular distortion in the octahedral coordination comes from the bites $\mathrm{O}(2)-\mathrm{Mo}(1)-\mathrm{O}(4)\left[159.93(8)^{\circ}\right]$ and $\mathrm{O}(1)-$ 
$\operatorname{Mo}(1)-\mathrm{N}(2)\left[159.85(8)^{\circ}\right]$. The dihedral angle between the two benzene rings of the Schiff base ligand is $112.0(5)^{\circ}$. In the complex, the coordinate bond lengths are comparable to those observed in molybdenum complexes with Schiff base ligands. ${ }^{12}$ The $\mathrm{Mo}(1)-\mathrm{O}(2)$ and $\mathrm{Mo}(1)-\mathrm{N}(1)$ bonds are much longer than usual, which is caused by the trans effects of the $\mathrm{Mo}=\mathrm{O}$ bonds. The $\mathrm{Mo}=\mathrm{O}$ bonds are also longer than usual, which might be caused by the formation of hydrogen bonds with adjacent groups (Table 3). In the crystal of the complex, molecules are linked through intermolecular $\mathrm{C}-\mathrm{H} \ldots \mathrm{O}$ hydrogen bonds (Table 3), to form a three-dimensional network (Fig. 2).

\section{3. Structure Description of the Nickel Complex}

The molecular structure of the complex is shown in Fig. 3. The asymmetric unit of the compound contains a linear trinuclear nickel(II) complex molecule and a water molecule of crystallization. The molecule of the complex possesses crystallographic two-fold rotation axis symmetry, with the inversion center located at the site of $\mathrm{Ni}(1)$ atom. There are three bridges across the $\mathrm{Ni} \cdots \mathrm{Ni}$ atom pairs, involving two phenolate $\mathrm{O}$ atoms of a Schiff base ligand, and an O-C-O moiety of a $\mu_{2}-\eta^{1}: \eta^{1}$-OAc group. The acetate bridges linking the central and terminal nickel atoms are mutually trans. The trinuclear nickel complex molecule consists of two NiL units connected to each other by a completely encapsulated third metal atom, $\mathrm{Ni}(1)$. The adjacent $\mathrm{Ni}(1) \cdots \mathrm{Ni}(2)$ distance is $3.018(1) \AA$.

The cage of $\mathrm{Ni}(1)$ is formed by phenolate bridges, $\mathrm{O}(1)$ and $\mathrm{O}(2)$, from the Schiff base ligands, and by two $\mathrm{O}$ atoms from two $\mu_{2}-\eta^{1}: \eta^{1}$-OAc ligands that furthermore connect the central metal with the two outer metal atoms resulting in an octahedral environment. The coordination around $\mathrm{Ni}(1)$ atom displays only slight distortion. The bond distances $\mathrm{Ni}-\mathrm{O}$ are relatively similar and range from 2.044(4) to 2.061(3) $\AA$. The greatest deviation of the bond angles from those expected for an ideal octahedral geometry is found for $\mathrm{O}(1)-\mathrm{Ni}(1)-\mathrm{O}(2)$ with $79.4(1)^{\circ}$, and $\mathrm{O}(1)-$ $\mathrm{Ni}(1)-\mathrm{O}(2 \mathrm{~A})$ with $100.6(1)^{\circ}$. The remaining bond angles are close to the ideal values for the octahedral coordination.

The coordination around the inversion-related terminal $\mathrm{Ni}$ atoms is also octahedral, with two imino $\mathrm{N}$ and two phenolate $\mathrm{O}$ atoms from a Schiff base ligand defining the equatorial plane, and with two $\mathrm{O}$ atoms respectively from a $\mu_{1}-\eta^{1}: \eta^{0}$-OAc and a $\mu_{2}-\eta^{1}: \eta^{1}$-OAc ligands occupying the axial positions. The coordination around the terminal metal atoms also displays slight distortion. The greatest deviation of the bond angles from those expected for an ideal octahedral geometry is $\mathrm{O}(1)-\mathrm{Ni}(2)-\mathrm{O}(2)$ $\left(82.5(1)^{\circ}\right)$, which is caused by the strain created by the four-membered chelate ring $\mathrm{Ni}(1)-\mathrm{O}(1)-\mathrm{Ni}(2)-\mathrm{O}(2)$.

The NiL units in the complex are butterfly-shaped, with the dihedral angles formed by the two benzene rings of the Schiff base ligands of $57.5(5)^{\circ}$. In the crystal structure of the complex (Fig. 4), the methanol molecules are linked to the nickel complex molecules through $\mathrm{O}-\mathrm{H} \ldots \mathrm{O}$ hydrogen bonds (Table 3 ). In addition, there are $\pi \cdots \pi$ stacking interactions among the benzene rings defined by atoms $\mathrm{C}(1) / \mathrm{C}(2) / \mathrm{C}(3) / \mathrm{C}(4) / \mathrm{C}(5) / \mathrm{C}(6)$ and $\mathrm{C}(12 \mathrm{~A}) /$ $\mathrm{C}(13 \mathrm{~A}) / \mathrm{C}(14 \mathrm{~A}) / \mathrm{C}(15 \mathrm{~A}) / \mathrm{C}(16 \mathrm{~A}) / \mathrm{C}(17 \mathrm{~A})$ [symmetry code for A: $-x, 1-y, 1-z$; centroid-centroid distance 4.873(3) $\AA$, the angle between the planes $57^{\circ}$; the perpendicular distance between the planes 3.593(6) ̊] in the complex.

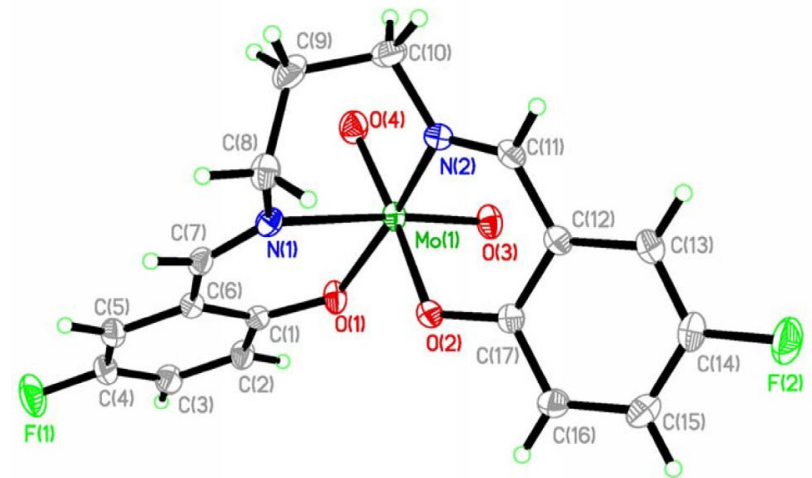

Fig. 1. Molecular structure of the molybdenum complex at $30 \%$ probability thermal ellipsoids.

\section{4. IR and UV-Vis Spectra}

In the infrared spectra of the free Schiff bases, there showed stretching band attributed to $\mathrm{C}=\mathrm{N}$ and $\mathrm{OH}$ at 1638-1645 and $3370 \mathrm{~cm}^{-1}$, respectively. In the spectra of the complexes, the $v_{\mathrm{C}=\mathrm{N}}$ bands were observed at lower fre-

Table 3. Distances $(\AA)$ and angles $\left({ }^{\circ}\right)$ involving hydrogen bonding of the complexes

\begin{tabular}{lcccc}
\hline $\boldsymbol{D}-\mathbf{H} \cdots \boldsymbol{A}$ & $\mathbf{d}(\boldsymbol{D}-\mathbf{H})$ & $\mathbf{d}(\mathbf{H} \cdot \boldsymbol{A})$ & $\mathbf{d}(\boldsymbol{D} \cdots \boldsymbol{A})$ & Angle $(\boldsymbol{D}-\mathbf{H} \cdots \boldsymbol{A})$ \\
\hline The molybdenum complex & & & & \\
$\mathrm{C}(3)-\mathrm{H}(3) \cdots \mathrm{O}(3)^{\mathrm{i}}$ & 0.93 & $2.57(3)$ & $3.1980(6)$ & $125(4)$ \\
$\mathrm{C}(10)-\mathrm{H}(10 \mathrm{~A}) \cdots \mathrm{O}(4)$ & 0.97 & $2.53(3)$ & $2.8760(5)$ & $101(5)$ \\
$\mathrm{C}(11)-\mathrm{H}(11) \cdots \mathrm{O}(3)^{\mathrm{ii}}$ & 0.93 & $2.48(4)$ & $3.1287(6)$ & $127(5)$ \\
$\mathrm{C}(13)-\mathrm{H}(13) \cdots \mathrm{O}(4)^{\mathrm{ii}}$ & 0.93 & $2.56(4)$ & $3.2410(6)$ & $131(5)$ \\
The nickel complex & & & & $143(4)$ \\
$\mathrm{O}(7)-\mathrm{H}(7 \mathrm{~A}) \cdots \mathrm{O}(8)^{\mathrm{iii}}$ & 0.82 & $2.07(3)$ & $2.77(2)$ & \\
\hline
\end{tabular}

Symmetry codes: i: $1-x,-y,-z$; ii: $2-x,-y, 1-z$. 


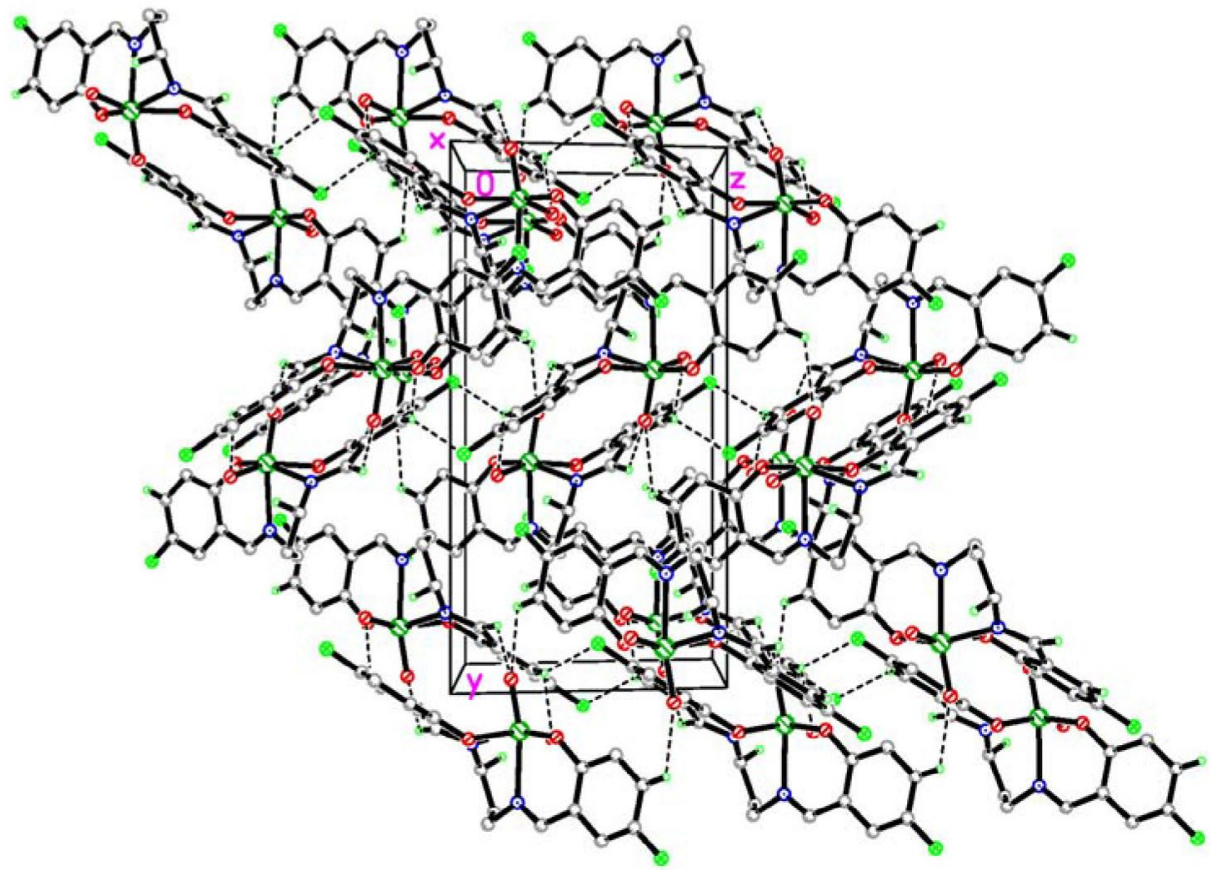

Fig. 2. Molecular packing structure of the molybdenum complex, viewed along the $x$-axis direction. Hydrogen bonds are drawn as dotted lines.

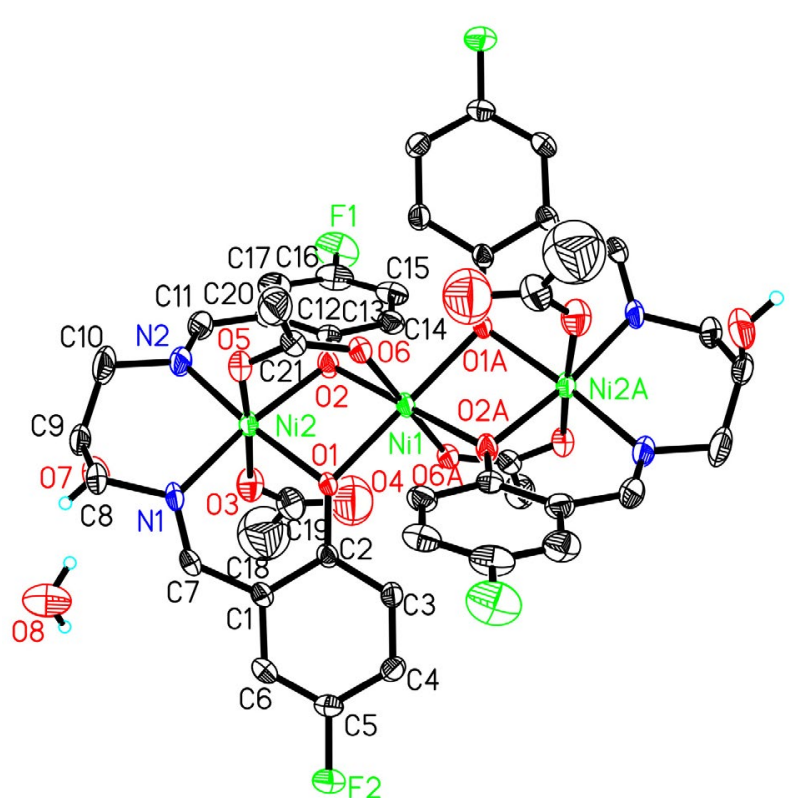

Fig. 3. Molecular structure of the nickel complex. Displacement ellipsoids are drawn at the $30 \%$ probability level and $\mathrm{H}$ atoms are shown as small spheres of arbitrary radii. Atoms labeled with the suffix A or unlabeled are related to the symmetry position $-\mathrm{x}, 1-\mathrm{y}, 1-\mathrm{z}$.

quencies, viz. $1621-1634 \mathrm{~cm}^{-1} \cdot{ }^{13}$ In the spectrum of the molybdenum complex, there showed two prominent bands at 977 and $895 \mathrm{~cm}^{-1}$, which attributed to dioxomolybdenum groups. ${ }^{14}$ In the spectrum of the nickel complex, there exhibits typical acetate vibrations $v_{\text {asym }}(\mathrm{OAc})$ at $1563 \mathrm{~cm}^{-1}$ and $v_{\text {sym }}(\mathrm{OAc})$ at $1450 \mathrm{~cm}^{-1} .{ }^{15}$ The bands due to $v_{\mathrm{C}=\mathrm{O}}$ are absent in both the free Schiff bases and the complexes. This suggests the formation of the azomethine

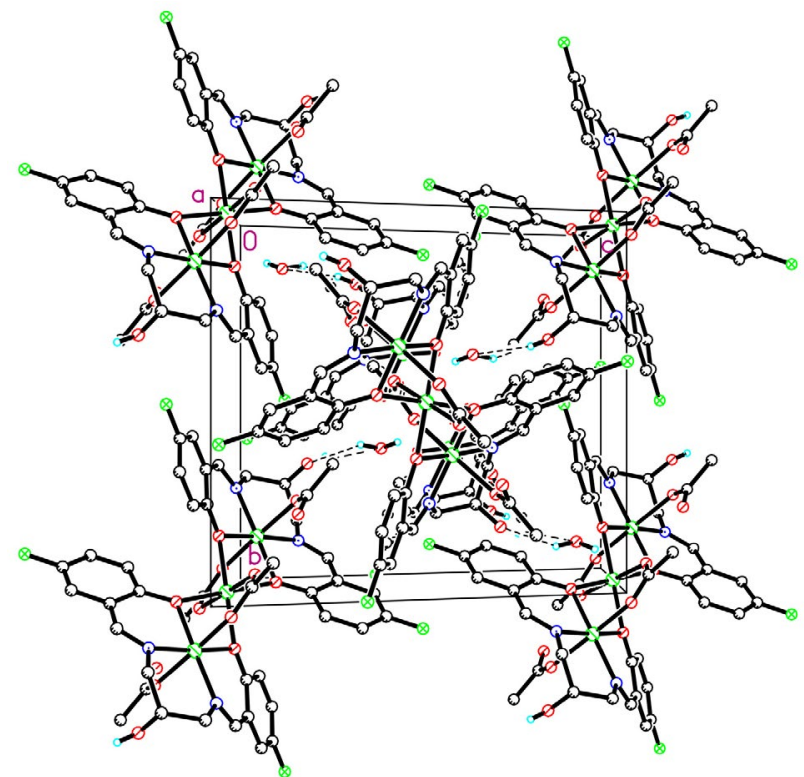

Fig. 4. Molecular packing diagram of the nickel complex, viewed along the $a$ axis. Hydrogen bonds are drawn as dashed lines.

groups, $\mathrm{CH}=\mathrm{N}$, during the condensation reaction of the starting material. The weak bands in the low wave numbers are assigned to the Mo-O and Mo-N vibrations.

The electronic spectra of the complexes were recorded in methanol. In the molybdenum complex, there showed bands at $325 \mathrm{~nm}$ and weak band at $420 \mathrm{~nm}$. The weak band is attributed to intra-molecular charge transfer transitions from the $p_{\pi}$ orbital on the nitrogen and oxygen to the empty $d$ orbitals of the metal. The intense band ob- 
served at $270 \mathrm{~nm}$ is assigned to intra-ligand $\pi-\pi^{*}$ transitions. In the nickel complex, the azomethine chromophore $\pi-\pi^{*}$ transition is located at $361 \mathrm{~nm}$. The broad non-symmetric band with absorption maximum at $420 \mathrm{~nm}$ can be assigned as LMCT.

\section{5. Catalytic Property of the Complexes}

Catalytic oxidation test of the complexes on the oxidation of sulfides under homogeneous conditions in solution using methyl phenyl sulfide (thioanisol) as substrate is shown as Scheme 3. As oxidant hydrogen peroxide was used in a slight excess of 1.25 equivalents based on the sulfide substrate. Reactions were run with $1 \mathrm{~mol} \%$ of catalyst based on the substrate at a temperature of $10^{\circ} \mathrm{C}$. NMR technique has been used to monitor the formation of the sulfoxides with 1,3,5-trimethoxybenzene (TMB) as internal standard to determine the yields. The reaction was started by the addition of hydrogen peroxide. A control reaction under the same condition without any complex present leads to less than $1 \%$ sulfide conversion within $4 \mathrm{~h}$. In the presence of the molybdenum complex conversion of $94 \%$ of sulfide to the corresponding sulfoxide within 60 min reaction time was observed. After about $2 \mathrm{~h}$ in all cases the conversions of total amount of sulfide were completed. Under the given conditions no over oxidation to the sulfone could be detected. However, the nickel complex has no activity on the reaction. Thus, the molybdenum complex showed excellent catalytic property for the sulfoxidation reaction.

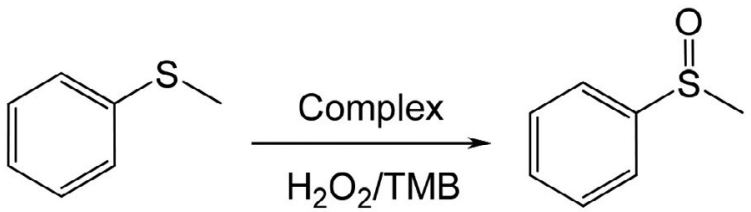

Scheme 2. The sulfoxidation process.

\section{Supplementary Materials}

CCDC-1870626 and 1465136 contain the supplementary crystallographic data for this paper. The data can be obtained free of charge at http://www.ccdc.cam.ac.uk/ const/retrieving.html or from the Cambridge Crystallographic Data Centre (CCDC), 12 Union Road, Cambridge CB2 1EZ, UK; fax: $+44(0) 1223-336033$ or e-mail: deposit@ccdc.cam.ac.uk.

\section{Acknowledgements}

This research was supported by the Top-class foundation of Pingdingshan University (no. PXY-BSQD2018006 and PXY-PYJJ-2018002).

\section{References}

1. (a) C. A. Gamelas, A. C. Gomes, S. M. Bruno, F. A. A. Paz, A. A. Valente, M. Pillinger, C. C. Romao, I. S. Goncalves, Dalton Trans. 2012, 41, 3474-3484; DOI:10.1039/c2dt11751g

(b) L. S. Feng, J. S. Maass, R. L. Luck, Inorg. Chim. Acta 2011, 373, 85-92; DOI:10.1016/j.ica.2011.03.060

(c) M. Bagherzadeh, M. Amini, A. Ellern, L. K. Woo, Inorg. Chem. Commun. 2012, 15, 52-55;

DOI:10.1016/j.inoche.2011.09.037

(d) S. Rayati, N. Rafiee, A. Wojtczak, Inorg. Chim. Acta 2012, 386, 27-35. DOI:10.1016/j.ica.2012.02.005

2. (a) B. I. Ceylan, Y. D. Kurt, B. Ulkuseven, J. Coord. Chem. 2009, 62, 757-766; DOI:10.1080/00958970802339669

(b) M. N. Sokolov, M. A. Mikhailov, P. A. Abramov, V. P. Fedin, J. Struct. Chem. 2012, 53, 197-201;

(c) S.-P. Gao, J. Coord. Chem. 2011, 64, 2869-2877.

DOI:10.1080/00958972.2011.608163

3. (a) S. Mandal, R. Saha, B. Mahanti, M. Fleck, D. Bandyopadhyay, Inorg. Chim. Acta 2012, 387, 1-7;

DOI:10.1016/j.ica.2011.12.035

(b) M. A. Vazquez-Fernandez, M. I. Fernandez-Garcia, A. M. Gonzalez-Noya, M. Maneiro, M. R. Bermejo, M. J. Rodriguez-Douton, Polyhedron 2012, 31, 379-385;

DOI:10.1016/j.poly.2011.09.031

(c) F. Habib, P.-H. Lin, J. Long, I. Korobkov, W. Wernsdorfer, M. Murugesu, J. Am. Chem. Soc. 2011, 133, 8830-8833.

DOI: $10.1021 /$ ja2017009

4. (a) N. K. Ngan, K. M. Lo, C. S. R. Wong, Polyhedron 2012, 33, 235-251; DOI:10.1016/j.poly.2011.11.057

(b) S. Duman, I. Kizilcikli, A. Koca, M. Akkurt, B. Ulkuseven, Polyhedron 2010, 29, 2924-2932;

DOI:10.1016/j.poly.2010.07.022

(c) R. D. Chakravarthy, K. Suresh, V. Ramkumar, D. K. Chand, Inorg. Chim. Acta 2011, 376, 57-63;

DOI:10.1016/j.ica.2011.05.033

(d) C. P. Rao, A. Sreedhara, P. V. Rao, M. B. Verghese, K. Rissanen, E. Kolehmainen, N. K. Lokanath, M. A. Sridhar, I. S. Prasad, J. Chem. Soc. Dalton Trans. 1998, 2383-2393.

5. (a) M. Mancka, W. Plass, Inorg. Chem. Commun. 2007, 10, 677-680; DOI:10.1016/j.inoche.2007.02.029

(b) S. N. Rao, N. Kathale, N. N. Rao, K. N. Munshi, Inorg. Chim. Acta 2007, 360, 4010-4016;

DOI:10.1016/j.ica.2007.05.035

(c) R. Dinda, S. Ghosh, L. R. Falvello, M. Tomas, T. C. W. Mak, Polyhedron 2006, 25, 2375-2382.

DOI:10.1016/j.poly.2006.02.002

6. (a) L. Wang, Y. J. Han, Q. B. Li, L. W. Xue, Russ. J. Coord. Chem. 2017, 43, 389-395; DOI:10.1134/S1070328417060094

(b) Q.-B. Li, Y.-J. Han, G.-Q. Zhao, L.-W. Xue, Acta Chim. Slov. 2017, 64, 500-505. DOI:10.17344/acsi.2017.3416

7. (a) L. Shi, Z.-P. Xiao, Z. Zhuang, H.-L. Zhu, Acta Crystallogr. 2007, E63, o4726;

(b) L.-W. Xue, Y.-J. Han, G.-Q. Zhao, Y.-X. Feng, J. Chem. Crystallogr. 2011, 41, 1599-1603.

DOI:10.1007/s10870-011-0146-Z 
8. Bruker, SMART and SAINT. Area Detector Control and Integration Software; Bruker Analytical X-ray Instruments Inc.: Madison, WI, USA, 1997.

9. G. M. Sheldrick, SADABS. Program for Empirical Absorption Correction of Area Detector Data; University of Göttingen: Göttingen, Germany, 1997.

10. A. C. T. North, D. C. Phillips, F. S. Mathews, Acta Crystallogr. 1968, A24, 351-355. DOI:10.1107/S0567739468000707

11. G. M. Sheldrick, SHELXL-97. Program for the Refinement of Crystal Structures; University of Göttingen: Göttingen, Germany, 1997.
12. (a) S. N. Rao, K. N. Munshi, N. N. Rao, M. M. Bhadbhade, E. Suresh, Polyhedron 1999, 18, 2491-2497; (b) W.-X. Xu, W.-H. Li, Synth. React. Inorg. Met.-Org. Nano-Met. Chem. 2012, 42, 160-164. DOI:10.1016/S0277-5387(99)00139-4

13. G. Romanowski, M. Wera, Polyhedron 2010, 29, 2747-2754. DOI:10.1016/j.poly.2010.06.030

14. T. Głowiak, L. Jerzykiewicz, J. A. Sobczak, J. J. Ziolkowski, Inorg. Chim. Acta 2003, 356, 387-392.

DOI:10.1016/S0020-1693(03)00301-3

15. B.-H. Ye, X.-Y. Li, I. D. Williams, X.-M. Chen, Inorg. Chem. 2002, 41, 6426-6431. DOI:10.1021/ic025806+

\section{Povzetek}

Sintetizirali smo nov enojedrni dioksomolibdenov(VI) kompleks, $\left[\mathrm{MoO}_{2} \mathrm{~L}^{1}\right]$, in nov linearni trijedrni nikljev(II) kompleks, $\left[\mathrm{Ni}\left\{\mathrm{NiL}^{2}\left(\mu_{1}-\eta^{1}: \eta^{0}-\mathrm{OAc}\right)\left(\mu_{2}-\eta^{1}: \eta^{1}-\mathrm{OAc}\right)\right\}_{2}\right] \cdot \mathrm{H}_{2} \mathrm{O}$, kjer je $\mathrm{L}^{1}$ dianionska oblika $N, N^{\prime}$-bis(5-fluorosaliciliden)-1,3-propandiamina $\left(\mathrm{H}_{2} \mathrm{~L}^{1}\right)$ in $\mathrm{L}^{2}$ dianionska oblika $N, N^{\prime}$-bis(5-fluoro-2-hidroksibenziliden)-2-hidroksi-1,3-propandiamina $\left(\mathrm{H}_{2} \mathrm{~L}^{2}\right)$. Kompleksa smo okarakterizirali $\mathrm{z}$ elementno analizo, FT-IR spektroskopijo in monokristalno rentgensko difrakcijo. V molibdenovem kompleksu je Mo atom oktaedrično koordiniran s štirimi donorskimi atomi Schiffove baze ter $\mathrm{z}$ dvema okso skupinama. V nikljevem kompleksu so prisotni trije mostovi med Ni-Ni pari atomov, ki vsebujejo dva fenolatna $\mathrm{O}$ atoma Schiffove baze in $\mathrm{O}-\mathrm{C}-\mathrm{O}$ skupino $\mu_{2}-\eta^{1}: \eta^{1}-\mathrm{OAc}$ liganda. Sredinski Ni atom leži na centru inverzije in ima oktaedrično koordinacijo s štirimi mostovnimi $\mathrm{O}$ atomi dveh Schiffovih baz v ekvatorialni legi ter $\mathrm{z}$ dvema $\mathrm{O}$ atomoma $\mathrm{z}$ dveh $\mu_{2}-\eta^{1}: \eta^{1}$-OAc ligandov v aksialni legi. Koordinacija okoli terminalnih Ni atomov je tudi oktaedrična $\mathrm{z}$ dvema imino $\mathrm{N}$ atomoma in dvema fenolato $\mathrm{O}$ atomoma Schiffove baze v ekvatorialni legi ter $\mathrm{z}$ dvema $\mathrm{O}$ atomoma $\mu_{1^{-}}$ $\eta^{1}: \eta^{0}$-OAc in $\mu_{2}-\eta^{1}: \eta^{1}$-OAc ligandov $v$ aksialni legi. Molibdenov kompleks ima odlične katalitične lastnosti pri reakciji sulfoksidacije. 